\title{
Michel Foucault na Universidade de São Paulo
}

\author{
Ricardo Parro \& Anderson Lima da Silva ${ }^{1}$ \\ Universidade de São Paulo
}

Michel Foucault esteve no Departamento de Filosofia da Universidade de São Paulo em duas ocasiōes: outubro de 1965 e, dez anos depois, em outubro de 1975. Nesses dez anos de intervalo Foucault deixou de ser um professor universitário pouco conhecido para se tornar um intelectual de celebridade mundial. $\mathrm{O}$ evento catalisador de sua fama foi a publicação, em 1966, de As palavras e as coisas - justamente o livro cujos manuscritos serviram de base às suas primeiras conferências na Universidade de São Paulo e que, conforme podemos ler nas Obras Completas de Foucault (Gallimard, 2015, vol. I, p. LI), teria sido "reescrito, por assim dizer, sob os olhos de Gérard Lebrun", então professor no Departamento. Em 1975, mesmo ano de lançamento de Vigiar e punir, Foucault desembarcou em São Paulo para uma série de conferências. Desnecessário lembrar que o período que cobre as visitas de Foucault à usp foi marcado pelo recrudescimento da repressão conduzida pela ditadura militar, que atingiu diretamente a Universidade de São Paulo e seu Departamento de Filosofia. Na primeira vez em que esteve entre nós, Foucault ministrou suas aulas na rua Maria Antonia; nas outras ocasiōes, ou na outra ocasião, teve de fazê-lo nos infames barracōes em que o Departamento, ao lado de outras unidades, fora instalado, no que posteriormente viria a ser o campus da Cidade Universitária.

O leitor encontrará aqui depoimentos de alguns dos que assistiram a essas conferências, professores ou estudantes não somente do Departamento de Filosofia como também de outras faculdades da Universidade de São Paulo. São impressões de teor subjetivo, que compóem um rico e vivo painel, necessariamente parcial, de

I Com a colaboração do corpo editorial da revista Discurso. 
momentos marcantes na vida do Departamento e da Universidade, e oferecem um registro vivo de um grande filósofo em ação. Os testemunhos a partir dos quais foi realizada a edição para este dossiê foram colhidos por Ricardo Parro, exceto pelos de Vitor Knoll e Heliana Conde, extraídos do artigo "Foucault na usP", de autoria de Caio Liudvik, publicado no número 159 da Revista cult; o de José Castilho Marques Neto, publicado no número 227 da revista culT; e o de Claudio Finzi Foà, extraído de seu livro Memories of a shrinked person (edição independente, São Paulo, 20I5). A transcrição integral do pronunciamento de Foucault na FAU-USP em 23 de outubro de 1975 foi realizada por Anderson Lima da Silva a partir de um documento do SNI (Serviço Nacional de Informações) datado de 1975 obtido junto ao Arquivo Nacional. Nesse pronunciamento, Foucault se solidariza aos estudantes que protestavam contra a onda de prisões de jornalistas, estudantes e professores da USP e anuncia a suspensão de suas aulas na Universidade, deixando seu curso inacabado - tal como ocorrera em 1965. No dia 25 de outubro, Vladimir Herzog foi assassinado sob tortura nas dependências do DOI-CODI. No dia 3I, Foucault participou da cerimônia ecumênica que reuniu mais de 8 mil pessoas na praça da Sé (ver Roberto Machado. Impressões de Michel Foucault. N-I edições, São Paulo, 20I7, pp. I22-I24). Durante esses eventos, relata a seu companheiro Daniel Defert ter a impressão de ser constantemente seguido; o serviço diplomático francês o informa que sua proteção está sendo assegurada por seus agentes (ver a "Cronologia" dos Ditos et escritos). Documentos oficiais do SNI, DOps e Ministério da Aeronáutica comprovam que a "impressão" de Foucault estava correta.

\section{Vitor Knoll}

Foucault esteve entre nós em 1965. A vinda dele foi promovida por [Gérard] Lebrun, que fora seu aluno na França e depois passou a manter relação bastante próxima com ele. Lebrun já estava entre nós — no Departamento de Filosofia desde 1960, graças ao programa que o governo francês mantinha desde a fundação da Faculdade de Filosofia, em 1934. Trata-se do mesmo programa pelo qual vieram [Claude] Lévi-Strauss, [Roger] Bastide e outros.

\section{José Arthur Giannotti}

Eu conheci Foucault numa visita a Jules Vuillemin, de quem nós tínhamos nos tornado muito amigos. E eu assisti as aulas de Vuillemin em 57-58 no Collège de France, não, na École Normale, na Rue d'Ulm. Depois eu fiquei muito amigo dele, nós nos entendíamos muito bem. Quando ele veio ao Brasil, fui até Brasília 
com ele num Volkswagen. Foi um grande amigo. Senti muito a morte dele [em 1984]. Bom, eu conheci Foucault num dia que Cruz Costa estava na França e eu o levei para casa do Vuillemin, que nos convidara para jantar. Estava lá um moço, e nós perguntamos, "O que você faz?", e ele havia publicado apenas o livro Doença mental e personalidade, de I954. Depois, levou-nos pra casa. A França tinha um professor em missão que era pago pela França e também pelo departamento (depois teve dois, voltou a ter um, e por fim cortou). Quem estava na época era o Lebrun, que tinha sido colega do Foucault, nos cursos de Jean Beaufret sobre Heidegger. Muito bem, aí o Lebrun disse, "por que não trazemos Foucault?" E propusemos ao Foucault que ele viesse. Ele topou. Ele veio, e deu um curso bem geral, que era Les mots et les choses. O Cruz Costa já não era mais chefe de departamento, acho que ele tinha se aposentado. Acho que eu era chefe naquele momento. Aí nós convidamos o Foucault, ele veio, e deu Les mots et les choses em premissa. No grupo, eu me lembro, estavam minha mulher, Lupe [Cotrim], Fernando Henrique [Cardoso], [Octavio] Ianni, um monte de gente. E ele falava muito na archéologie du savoir. A Lupe uma vez perguntou, a meu ver muito pertinentemente, "Foucault, além de você, alguém é capaz de usar esse método?" O que era a pura verdade. Eu sei também que eles iam, ele e o Lebrun, para o Rio de Janeiro, onde ele ficava corrigindo as provas [do livro].

\section{Marilena Chaui}

A primeira visita dele é a dos anos 6o. E, naquela época, o professor visitante vinha para dar um curso magistral. Então era um curso que era assistido pelos outros professores e, como na Maria Antônia estavam juntos todos os elementos da Faculdade de Filosofia, Ciências e Letras (FFCL), então o pessoal das ciências, os matemáticos, os físicos, o pessoal das letras juntamente com o pessoal da filosofia assistia os cursos dos professores convidados. Era um curso em que uma parte do público era constituída pelos professores da FFCL, outra pelos estudantes. Foi para esse público que o Foucault, como qualquer outro professor visitante da época, deu o seu curso. E o curso que ele deu foi o que viria a aparecer no ano seguinte na forma de livro, Les mots et les choses. Foi uma coisa absolutamente fantástica, ele levou um mês com aulas diárias, toda tarde, das duas às cinco da tarde todos os dias. Quando fez o primeiro conjunto de exposiçōes, eu me lembro que houve um grupo de professores, que estavam ligados ao grupo de leitura do Capital - Fernando Novais, Giannotti —, eles saíram da sala do curso, acho que depois da terceira aula, e o Fernando Novais dizia, "Mas esse sujeito é louco, esse sujeito é completamente louco. Não tem história no mundo dele. O mundo dele não tem tempo e não tem história. Como é que ele pode trabalhar com 
período de ideias desconsiderando inteiramente a história?” Então, o primeiro choque que o Foucault causou, entre nós, e que depois seria o choque que ele causaria na Europa, foi a descontinuidade. Foi o primeiro a trabalhar, a tematizar, embora não explicitamente, a operar implicitamente com a descontinuidade. E foi um deus nos acuda, porque todo mundo estava acostumado a trabalhar com a continuidade histórica, para o bem ou para o mal. Mas você trabalhava com o contínuo temporal. Por isso, foi realmente uma revolução conceitual que foi provocada, com reações as mais variadas do nosso corpo docente.

\section{Maria Beatriz Nizza da Silva}

Quando o Foucault veio ao Brasil, eu ainda estava no Departamento de Filosofia. E estava preparando [sob orientação do Bento] aquela tese que eu tinha começado com o Cruz Costa, que era sobre um publicista, não se pode chamar filósofo, o Silvestre Pinheiro Ferreira, que foi ministro de Dom João vi quando a corte veio de Portugal para o Brasil. Estava meio perdida, quer dizer, sem saber muito bem o que fazer, porque o Departamento de Filosofia era dos grandes nomes da filosofia, Kant, Hegel, etc. Eu não estava no meu ambiente. Veio o Foucault, e na primeira aula dele eu disse: "isso é o que realmente vai me abrir..., porque eu, com esta gente aqui à minha volta, não me entendo". Foi antes de ele publicar Les mots et les choses, que é de 66. O que ele veio dar foi praticamente o conteúdo do livro. Ele era brilhante a falar. No fim, quando acabou o curso, o pessoal do Departamento de Filosofia, o Giannotti, diziam, "Ah, ele não é filósofo, é historiador". Bom, para ele já ficou marcado que o Foucault não era filósofo, era historiador. Para mim, abriu um monte de caminhos, porque ele não se prendeu aos grandes nomes da filosofia. Depois, foi interessante quando em 69 viajei a Paris com uma bolsa - meu marido também [João Paulo Monteiro]. Eu ia sempre à Biblioteca Nacional, trabalhar, pois estava estudando o século XVIII francês, e o Foucault estava lá todos os dias. Eu ia todos os dias, todos os dias o Foucault estava lá. Por quê? Porque ele era um erudito, que delineava o seu próprio campo e pegava autores que ninguém lia. Quer dizer, autores que ninguém sabia quem eram. Eu sabia. Por causa do Silvestre Pinheiro Ferreira eu tinha feito uma pesquisa daqueles pequenos autores que estavam esquecidos nas bibliotecas. Eu lembro de ter ido à biblioteca da Faculdade de Direito, no Largo São Francisco, pedir obra de ciência política do século XviII; a moça vinha com os livros cheios de pó, porque ninguém mexia naquilo. Eram teóricos políticos que ninguém mais conhece, mas que eram lidos. De certa maneira, o Foucault abriu o caminho para uma área que é a história do livro e da leitura. Ele ia trabalhar nas bibliotecas e descobria aquilo que se lia na época e era importante, não o que passou à posteridade. Era 
preciso saber o que efetivamente as pessoas liam, qual era o universo, o paradigma dessas pessoas, aquilo que fazia o saber delas. E é a partir daí que ele desenvolveu todos os seus livros. Eu acho que ele fez uma revolução numa área que era uma área meio indefinida. Ele também não se intitulava filósofo, ele se intitulava, no fundo... Ele nem queria um rótulo. Mas, de qualquer maneira, era muito mais historiador. Nisso o Giannotti tinha acertado, ele era muito mais historiador.

\section{José Arthur Giannotti}

O Foucault era um professor admirável. A maioria dos professores franceses são admiráveis. Eu lembro da época, do primeiro professor francês que eu vi funcionando que era Guéroult, dando Leibniz, um rigor danado. Entra um bedel na sala, no meio do curso, pede para ele assinar qualquer coisa; ele, falando, pega o papel, assina, continua a falar, dá um sorriso para o cara e continua a falar. Entendeu? Mas o Foucault era, às vezes, no Collège de France, como uma Pelerini - uma daquelas capas abertas: ele fazia uma encenação danada, muito interessante, às vezes exagerado. Enfim, o curso nos pegou bastante, vimos que tinha coisa nova, era muito interessante.

\section{Paulo Eduardo Arantes}

Em 1965 eu estava no primeiro ano na filosofia e o meu professor, meu guru era o Bento Prado, que era o encarregado da disciplina naquele ano. E, no fim do primeiro semestre mais ou menos, o Bento disse: "está vindo ao Brasil, como visiting" - era uma praxe do departamento, todo ano vinha um francês; eram dois postos franceses no departamento - "está vindo um cara que parece muito interessante, que foi professor do Lebrun, que o indicou". Então o departamento convidou esse professor do Lebrun, chamado Michel Foucault, que não era "Michel Foucault", era nobody. Ninguém sabia de sua existência, nem no Departamento... nada! Enfim, ele tinha passado - isso está na biografia dele [por Didier Eribon] — pela Tunísia, pela Argélia e pela Suécia, e tinha publicado dois, três livros, que ninguém conhecia. Mas o Bento disse, "olha, ele tem um livro, que o Lebrun nos indicou, chamado História da Loucura. O Bento tinha o original, e eu comprei em edição Ioxı8, que era resumida (risos). E li. E o Bento leu inteiro o outro, o livrão grande... O rapaz apareceu por aqui em agosto. Em agosto de 65. [sic.] E ficou até setembro, dando uma aula por semana, uma palestra por semana. [sic.] E chegou nessas condições, o antigo professor de Lebrun. Eu tinha lido a História da Loucura, o Bento também, nós discutíamos, e foi aquela revelação. Foucault, por mais barroco que fosse, causava certo choque. E acho que só nós dois lemos, acho, não sei se o Giannotti leu... Porchat nem pensar... não sei se Porchat chegou 
a folhear... E o Ruy? Também não sei se o Ruy leu. Não sei. Aí chegou o homem, terno e gravata, e careca daquele jeito, e dente de ouro: parecia personagem do Nelson Rodrigues (risos). O que é isso? Quem é esse cara? (risos) Então começa a primeira aula. Ninguém tinha a menor ideia, pouquíssimos sabiam quem ele era, do que ele era capaz, sabíamos que era um historiador, historiador das ideias, filósofo de formação, e... ponto. Ninguém tinha muita ideia. E ele começou a falar sobre pensamento renascentista, sobre Aldrovandi. Ninguém sabia quem era Aldrovandi, exceto pela Maria Beatriz. Mas a fluência dele... Não sei se você já viu vídeos dele. Era um negócio impressionante, já naquela época. Todo mundo de olho arregalado. E ele contando histórias do arco da velha. E foi assim durante todo o mês de agosto, uma vez por semana, acho que até meados de setembro. [sic.] A única coisa que se destacava nisso, depois de ele ter dado um mês e meio de aula, era, literalmente, que não sabíamos do que ele estava falando, ninguém tinha ideia. Era uma história das ciências humanas... De vez em quando, ele usava a palavra "arqueologia", uns nomes estranhos e tal. Só um ano depois, em 66, nós viemos a saber que o curso era Les mots et les choses. No Brasil ele estava terminando o livro, revendo as provas, escrevendo as coisas em cima e tal, dando a última demão. Nada menos que isto: Les mots et les choses, que estourou na França em 66, e foi vendido até em supermercado. O público não lotava uma classe de graduação na Maria Antônia, eram 30, 40 pessoas. Isso lembrando que o francês era a segunda língua, naquela época. E sobre o que ele falou? Exatamente sobre o que estaria no livro. Todos os comentários da plateia foram metodológicos, as observações foram todas metodológicas. A recepção foi de entusiasmo, porque ele era brilhante, e ao mesmo tempo morna, porque ninguém sabia o que fazer com aquilo. Ele gostava de fazer piadas antimarxistas, do tipo, "Marx, aquele grande filósofo do século xIx", Sartre, "o maior filósofo francês do século xIx". O Bento e eu, que éramos novidadeiros, gostávamos dessa coisa de episteme pra cá e pra lá... Mas o interessante era o seguinte: o Foucault enquanto tal, embora tenha fascinado as pessoas através da prosa e pela simpatia, era modesto, divertido...

\section{Ruy Fausto}

Nós fomos para a casa da Betty Milan, para o apartamento que ela tinha no Guarujá. E lá nós andamos pela praia... A gente conversava. Eu me lembro que havia um pouco de exibição. Lá no apartamento ele fazia piadas. A certa altura, a Betty Milan veio de manhã, estávamos conversando sobre Lévi-Strauss, troca de mulheres, e ela veio correndo com uma bandeja, escorregou e caiu; aí ele disse: "Eh, tiens, on n'a pas d'échanges de femmes". E então ela pulou, dizendo, "Quand on parlera de changer les hommes, on verra qui sautera le premier". (risos) 
Piada, trocadilho "Ó, vamos ver quem é que vai pular aî". Essas coisas ele fazia. Numa aula, ele fez uma brincadeira com o Traité de l'inversion, que é um livro de gramática geral ou coisa que o valha: "Ah, vocês não vão pensar que é outra coisa, o Traité de l'inversion". O curioso é que foi silêncio total, todo mundo com medo de ser agressivo, ninguém riu; o que foi muito pior, evidentemente - o silêncio absoluto. A revista Cult andou dizendo que ele foi mal recebido, que teve uma recepção horrível na usp, que ali só tinha marxistas. A verdade é que, marxista ou não, o recebemos de braços abertos, o adoramos. Claro que a gente ficava um pouco com o pé atrás, dava uns palpites. Eu me lembro que eu comecei a falar, "E o tempo nisso aí? Le temps ne fait rien à l'affaire" (que é uma melodia do Brassens). O Lebrun gostou muito desse "le temps ne fait rien à l'affaire". Quer dizer, a gente era muito ingênuo, mas a gente gostou muito. Inclusive porque vínhamos da escola do Guéroult. Você imagina o que foi isso, de repente o cara abriu as portas, e a figura dele era muito simpática. Eu me lembro que ele dizia, "Ah, vocês talvez precisassem de philosophe daqui, philosophe dali". Pois nessa época ele se dizia um não-filósofo. Nas aulas, a sala estava cheia, todo mundo lá, a gente adorava. Logo depois começou a repressão. Eu não me lembro bem as datas. No final, ele se despediu, esperando que tudo se arranjasse por aqui. Foi nessa estada que ele teria dito, "Eu tenho a impressão de que estou num departamento francês de ultramar". Se ele disse mesmo eu não sei, o Paulo Arantes talvez saiba.

\section{Marilena Chaui}

A partir de 1969 os professores franceses, que eram os nossos visitantes normais (raramente vinham professores visitantes de outro país), passaram a não vir ao Brasil, como atitude política. A primeira vez que eles compreenderam que era fundamental ajudar na resistência, os professores e estudantes que estavam na resistência, foi com o Jean-Pierre Vernant, e, depois, com o Foucault. O Vernant esteve por aqui em 72, antes da segunda vinda do Foucault, em 73, a terceira em 75. Na segunda vez, ele fez questão, mais até explicitamente do que o próprio Vernant, de propalar na imprensa, nas revistas, a quem o entrevistasse, que ele tinha vindo como apoio à resistência contra a ditadura. Ele participou de atividades políticas também fora da usp, ligadas à defesa dos direitos humanos, como o Tortura Nunca Mais, o Justiça e Paz, de discussões em torno da repressão aos homossexuais, e assinou vários manifestos, contra a tortura, em defesa dos presos políticos, e, depois, coisas mais gerais, como a questão do homossexualismo, do feminismo, que começava no Brasil. O que é interessante é que, na primeira vez, a presença do Foucault foi uma presença universitária, foi o que aconteceu dentro da usp. Na segunda vez, também, mas já com uma clara afirmação de que ele 
tinha vindo para auxiliar na resistência. Ele deu alguns seminários, e teve uma atuação extrauniversitária, com todos os movimentos de luta contra a ditadura. Foi muito corajoso, pois mesmo quando passamos a ter outros visitantes, eles não ultrapassavam a fronteira da universidade. O Foucault não, o Foucault foi pra rua. Ele chegou a participar de uma passeata no Rio, se não me engano. Isso eu não posso garantir pra você. Ele voltou uma terceira vez para São Paulo e eu me lembro que eu e a Maria Sylvia fomos lá no hotel, porque ele ia ser expulso do Brasil. Fomos lá para acertar tudo e garantir que ele não fosse expulso, porque ele havia se engajado. Ele foi muito corajoso. Depois ele não veio mais, não para a USP. Ele foi uma presença muito interessante, e marcou profundamente alguns dos professores que estavam começando, como a Maria Beatriz, que fez uma tese de doutorado baseada no esquema da episteme proposto pelo Foucault. O que é interessante é que o Foucault foi ter uma reverberação e uma presença muito forte junto aos historiadores, a partir dos anos 80, que, juntamente com os psicólogos, deram a ele um lugar de relevância que o pessoal da filosofia não deu. Por mil e uma razões, o grande reconhecimento público, vamos dizer assim, do Foucault no Brasil, não foi pela parte dos filósofos, mas pela dos historiadores e psicólogos.

\section{Franklin Leopoldo e Silva}

Na segunda vez que o Foucault veio, em 75, em circunstâncias muito diferentes, já com a ditadura bastante consolidada e a repressão muito feroz, foi num clima de grande compromisso político que ele não recusava. Ele sabia o que estava acontecendo, as pessoas o colocavam a par dos acontecimentos. E ele não só exercia uma atividade intelectual como ele também se posicionava de uma forma muito clara do ponto de vista político ou pelo menos tão clara quanto era possível para um professor visitante estrangeiro, que tinha problemas com a embaixada, com o consulado e não podia se expor muito. Mas, mesmo dentro desses limites, ele colaborou muito, principalmente do ponto de vista de uma certa orientação intelectual e com o movimento estudantil da época, que depositava grandes esperanças nele, no sentido de que ele viesse a dar apoio efetivo para o que estava acontecendo. E de fato ele o fez. Ele deu conferências e participou de encontros voltados para a situação política da época aqui no Brasil. Não sei muito bem qual seria a posição dele com relação ao que estava acontecendo, se ele tinha conhecimento suficiente para ter um juízo. Mas ele não recusou a se comprometer, a ajudar da maneira como ele podia. Ele deu ao ambiente da faculdade um certo otimismo, as pessoas ficaram satisfeitas com a presença dele ali, que não era alguém que veio apenas dar uma série de conferências. Mas essas conferências foram marcantes. Tinham uma linha, que correspondia àquilo que ele estava fazendo 
na época. Eu acredito que fosse algo na direção daquele livro que se seguiu às Palavras e as coisas, um livro praticamente metodológico, Arqueologia do saber. E A ordem do discurso, que havia sido aula no Collège de France. Eu me lembro que era mais ou menos por aí que as coisas se passavam, mas de uma forma muito livre, né? O que é constante no Foucault. As pessoas que ouvem até mesmo as gravações disponíveis, que leem o livro, elas acham uma diferença muito grande entre o que ele escrevia e o que ele falava. E naturalmente com muito mais ênfase no que ele falava, na aula mesmo. $\mathrm{O}$ pessoal reclama disso, porque as aulas são sempre editadas e publicadas, não correspondem a essa vivacidade da maneira como ele se portava diante o público.

\section{José Arthur Giannotti}

Ele veio mais uma vez depois de 1965, eu acho, em 1975, quando a faculdade estava tomada pela polícia, e ele se recusou a dar aula. "Eu não dou aula em faculdade ocupada". Certo? Depois ele foi ao Rio, onde teve uma recepção teórica obviamente melhor do que recebera em suas visitas a São Paulo. A última vez que eu vi Foucault foi correndo pelos corredores do Collège de France. Nunca fomos amigos, mas conversávamos bem; eu reclamava que ele sabia pouca lógica, e ele dizia, "Eu não entendo Wittgenstein, Giannotti!" E ele não entendia mesmo. E sempre reclamei da Archéologie du Savoir.

\section{Maria Lúcia Cacciola}

Em I975, foi quando morreu o Herzog. A história começou quando o Foucault se propôs a dar um curso lá na Filosofia, no auditório da Psicologia, que ficava nos antigos barracões, também chamados de Colmeias, onde eu estudei. Porque todos tinham saído da Maria Antônia, mas não havia uma instalação pronta pra nós. Eu tinha entrado em 70. Em 75 eu era professora recém-contratada. Era o tempo em que a gente podia ser professora como auxiliar de ensino. Fomos todos assisti-lo. Foi aquela animação: Foucault no auditório do Instituto de Psicologia, nos benditos barracões. Estava lá a nata dos intelectuais de São Paulo, você pode imaginar, para ver o Foucault, que a essa altura já era conhecidíssimo. Os psicanalistas, os psicólogos e os filósofos, enfim, todo mundo que você possa imaginar de mais conhecido em nossos círculos. Ele começou a falar sobre o cuidado de si, o que viria a ser aquele livro dele, Le souci de soi; e a falar, justamente, sobre a psicanálise. A apreciação que ele fazia da psicanálise não era das mais simpáticas, porque ele fazia uma comparação da psicanálise com a confissão religiosa, católica por excelência, que era uma espécie de extração da verdade de cada um. Não é a leitura que eu faço da psicanálise. Em todo caso, ele lia assim. E nisso, no meio da conversação, 
da palestra, entra um estudante que tinha um problema sério de... não sei se era psicopatologia ou psicose o que é, porque eu não conheço essas definições. Mas ele era aceito no departamento como se aceita o diverso, como Foucault recomenda... Ele dormia no centrinho, andava por lá, bebia cachaça, devia fumar maconha junto com os outros, entendeu? Quer dizer, eu imagino que ele tinha um trato especial. E às vezes ele ficava muito alterado. Principalmente quando bebia. A bebida, para a pessoa que tem alguma psicopatologia, é complicada. Eu sei que ele chegou com uma garrafa de pinga na porta do auditório. E o Foucault dizendo que a psicanálise era uma extração da verdade. E o aluno contrariando isso de uma certa maneira, porque o seu bordão era "eu quero a verdade" (risos). Ele fazendo o papel do advogado do diabo (risos): "eu quero a verdade". Alteradíssimo. E aí o Foucault foi ficando branco... Os olhos arregalados e tal. E o estudante lá, um homem forte... Aí ficou aquela cena. Ninguém queria ir lá falar com ele. E os olhos de todos os assistentes ficavam olhando para o Foucault falando, mas com o rabo do olho no estudante. Era engraçada, a cena. Ficou aquele "tititi" entre os professores: "que faremos?". E o pessoal da psicologia acho que pensou: "o rapaz é filósofo, então os filósofos que cuidem do problema, não temos nada com isso". Imagina eu, né? Por fim, o José Cavalcante foi chamado. Era o chefe da cadeira de grego, que estava emprestada para a filosofia... Era bem considerado, era chefe da cadeira. Filomena Hirata, e outros professores hoje já aposentados, foram discípulos dele. Havia uma coisa meio mítica em torno dele, sabe? Também fui aluna dele. E ele, com aquele jeitinho dele, foi lá e convenceu o tal estudante a sair. Nisso, o Foucault já tinha suspendido a aula... dizia-se que ele nunca havia feito isso. Suspendeu a aula por dez minutos, saiu. Foi uma situação terrível. Depois ele voltou, e terminou a conferência.

\section{Heliana Conde}

Entrevistadas de minha pesquisa referem-se, de forma um tanto distinta, a uma curiosa ocorrência durante a primeira aula (a única? - permanece a dúvida) do curso de 1975. Concordam que certo aluno - personagem conhecido, que vivia na própria universidade sob os cuidados dos colegas - entrou no auditório onde Foucault estava lecionando e interrompeu o discurso do filósofo. A partir daí, contudo, os relatos divergem: algumas falam de uma cena explícita de masturbação, que teria durado um tempo enorme; outras concordam ter havido algo análogo, embora de caráter menos "sensacional"; outras ainda limitam-se a registrar que Foucault foi interrompido pela entrada de um "homem infame" - usando conhecida expressão do próprio Foucault. As diferenças nas lembranças não param por aí: segundo uma entrevistada, muitos e muitos encontros no bar onde os alunos 
da USP costumavam beber cerveja foram gastos debatendo a atitude de Foucault, que teria, severamente, convidado o rapaz a se retirar do auditório. Conforme recorda outra, o filósofo, elegantemente, apenas propôs que se fizesse um intervalo, e os colegas do aluno que entrara intempestivamente é que tomaram providências para que este saísse do local. Finalmente, outra evoca um Foucault que permitiu que o "infame" falasse, sem adotar qualquer medida restritiva - ao contrário, teria coerentemente encerrado a própria aula aproveitando o propício incidente.

\section{José Castilho Marques Neto}

A primeira vez que o vi foi atendendo a um chamado de socorro dos organizadores que me procuraram, e à Vânia, para convencer nosso colega Luiz Gonzaga, que sofria de alguns distúrbios emocionais, a se retirar da frente da mesa onde Foucault ministrava sua conferência. Com uma garrafa de cachaça na mão, já alterado, Luiz falava alto: "Bobagem", "Mentiras", para o espanto do culto auditório. O clima estava quase hostil para com ele e entre os poucos olhares de compreensão e de aceitação daquela contravenção explícita da ordem, estava o de Foucault. Delicadamente conversamos com nosso amigo e o conduzimos para seu habitat naqueles anos, o CAF [Centro Acadêmico de Filosofia]. Mas me sobrou o olhar não discriminatório do ilustre palestrante.

\section{Paulo Eduardo Arantes}

Numa de suas aulas, Foucault fez uma referência à Revolução dos Cravos, que é de, exatamente, abril de 75. "Eu não tenho ilusões a respeito da Revolução dos Cravos, porque se não houver democracia pela base, com a hegemonia do Partido Comunista, não vai, vai desandar novamente". Todo mundo entusiasmado com a Revolução, e ele com o pé atrás.

\section{Claudio Finzi Foà}

Era o mês de outubro de 1975, o jornalista Vladimir Herzog havia sido morto alguns dias antes. No campus da USP, nós todos havíamos paralisado as aulas para preparar o ato de protesto da sexta-feira seguinte. Creio que foi na segunda-feira daquela semana, e estávamos todos consternados com o que acontecera nos porões do DOI-CODI. Era o maior sobe e desce pelas rampas da FAU (onde eu estudava), e a cada minuto eu cruzava com o pessoal do Grêmio, do DCE. Em uma dessas subidas de rampa, vinha em sentido oposto ao meu um grupo de estudantes que eu conhecia bem (lembro da Clara Ant, do Josimar Melo), acompanhado de um senhor de terno e gola olímpica, sem gravata, cara meio esquisita, totalmente careca. Na hora em que ele me viu, estancou e ficou me fitando, como quem vira 
um extraterrestre. Continuei meu caminho, e percebi que o cara ficava olhando para trás (para mim), atônito. Menos de uma hora depois começava, no salão Caramelo da FAU, a assembleia. Sentado à mesa, junto do pessoal, estava o dito-cujo senhor. Após as primeiras falas deliberativas, um dos membros da mesa anunciou a presença solidária de Michel Foucault, conhecido filósofo e ensaísta francês que estava de passagem por São Paulo. Durante essa longa estadia, o Foucault concedeu pelo menos uma longa entrevista a um dos órgãos da imprensa alternativa. Eu, na época, colecionava um monte dos ditos jornais "nanicos", então não lembro ao certo se foi no Ex ou no Versus que tomei contato com o pensamento dele, e com o seu discurso sobre excluídos, em especial os doentes mentais. Não me lembro se foi antes ou depois desse episódio que comecei a me interessar pelo tema da doença mental. Sei que carreguei com certo orgulho a ideia de que teria sido "objeto de estudo" do Foucault.

\section{José Castilho Marques Neto}

A chegada à FAU criou um justificado murmúrio na assembleia que já estava acontecendo. Levei-o aos bastidores onde alguns colegas já o esperavam. Ele pediu papel, sentou-se à mesa e rapidamente escreveu um pequeno texto de dois parágrafos. Glauco fez a tradução para o português, alguns revisaram e me coube ler a versão para a assembleia ao lado de Foucault que leu o texto em francês. Aplausos emocionados, vibração genuína pelas palavras fortes do filósofo que se recusava a continuar dando aulas num país que prendia e torturava intelectuais e trabalhadores.

\section{Documento do SNI}

$\mathrm{Na}$ assembleia universitária de 3 de outubro de 1975 assim se pronunciou o nominado: "Muitas dezenas de estudantes e professores da usp foram recentemente presos. Talvez sejam torturados — se é que já não o estão sendo neste momento. Suas vidas estão ameaçadas. Uma Universidade que não é plenamente livre não passa de uma empresa de servilidade. // Não dá para lecionar sob o tacão das botas; não dá para falar diante dos muros de prisões; não dá para estudar quando as armas ameaçam. A liberdade de expressão e de pesquisa são sinais de garantia da liberdade dos povos. Na defesa dos direitos, na luta contra as torturas e a infâmia da polícia, as lutas dos trabalhadores intelectuais se unem às dos trabalhadores manuais. // A Universidade de São Paulo saiba que sua luta de hoje relaciona-se à luta pela liberdade em todos os países do mundo. Presto minha homenagem à sua coragem e me associo de bom grado às decisôes que vocês possam tomar para conseguir que a justiça aqui não seja uma palavra ultrajada”. Na mesma 
assembleia referida, foi aprovado que o epigrafado suspendesse seus trabalhos no País, enquanto não libertarem os estudantes presos e que produza artigos dando seu ponto de vista sobre as prisóes e denunciando amplamente na imprensa internacional, particularmente na França.

\section{Maria Lúcia Cacciola}

Ele teve que ir embora, infelizmente, porque mataram o Herzog. Ele tomou o avião não sei se no dia seguinte ou poucos dias depois da morte. Não acabou o curso nem deu mais nenhuma lição. Foi-se embora daqui horrorizado. O que eu guardo dessa visita é o episódio que já mencionei, do tal estudante. O interessante é que o que ele disse tinha sentido, diante da conferência: "eu quero a verdade". Ora, o Foucault estava criticando justamente a extração da verdade; então vem o louco e diz "não, mas eu quero a verdade". É o contrário da desrazão foucaultiana. De certo modo, ele estava provando um pouco a história de que a desrazão também faz parte da razão, não é algo exterior a ela, não é uma anomalia, uma coisa de fora, que tem que ser tratada como não-humana ou doentia.

Os registros das passagens de Foucault pelo Brasil foram coligidos nos dois volumes dos Dits et écrits (Éditions Gallimard “Quarto”, 200I), e resumem-se às seguintes publicações: um brevíssimo texto intitulado "O mundo é um grande asilo", publicado, bizarramente, pela revista de variedades Manchete, da editora Bloch, em 16/6/1973 [texto n. I26 dos Dits et écrits]; uma série de conferências, "A verdade e as formas jurídicas”, ministradas na PUC-Rio entre 2I e 25 de maio de 1973 , publicadas em junho de 1974 nos Cadernos pUC (no. 16 ) [texto n. I39]; fragmentos de uma conferência em Belo Horizonte, publicada no jornal Estado de Minas em 30 de maio de 1973 sob o título "Foucault, o filósofo, está falando. Pense" [texto n. I24]; uma entrevista concedida ao Jornal do Brasil, intitulada "Loucura, uma questão de poder", publicada em I2/II/I974 [texto n. I4I]; a primeira [texto n. I70] e a segunda [texto n. 196] conferências pronunciadas no curso de medicina social da Universidade Estadual do Rio de Janeiro em outubro de 1974 [texto n. 196]; uma entrevista concedida a um grupo de psicanalistas e psiquiatras paulistas, publicada no primeiro número da revista Versus, em outubro de 1975, com o título "Asilos. Sexualidade. Prisões" [texto n. I60]; uma entrevista publicada no Jornal da Tarde em I/II/1975, intitulada "Michel Foucault. O filósofo responde" [texto n. I63]; a primeira e a segunda partes de uma conferência pronunciada na Faculdade de Filosofia da Universidade Federal da Bahia em 1976, intitulada "As 
malhas do poder" [texto n. 297]; e, por fim, fora dos Ditos e escritos, o texto de Foucault pronunciado na assembleia da FAU em outubro de 1975, publicado pelo Jornal ex, de 6 novembro de 1975, portando o irreverente título "Uma aula de Fucô” (https://pt.scribd.com/document/I55155743/Jornal-eX-I6-Novembro-1975).

Os documentos reproduzidos a seguir contam uma história curiosa. Alguns atestam as tratativas entre Foucault e o Departamento relativas à vinda do filósofo em I975: uma carta do próprio Foucault, datada de 13 de abril (provavelmente de 1974) [imagem 3]; uma carta da então chefe de departamento, Maria Sylvia de Carvalho Franco, comunicando a Foucault o programa previsto de suas atividades didáticas na UsP [imagem 4]; outra carta, da mesma Maria Sylvia, endereçada ao adido cultural da França em São Paulo, solicitando providências para a vinda de Foucault, juntamente com Alain Grosrichard [imagem 5]. Dois outros documentos registram desencontros: um convite de Lívio Teixeira, datado de março de 1966, para que Foucault ministrasse um curso de ética, em lugar de Michel Debrun [imagem I]; e a confirmação, datada de I967, endereçada pelo cônsul francês em São Paulo a José Arthur Giannotti, chefe de departamento, de que o consulado estaria disposto a se encarregar dos custos de uma eventual vinda de Foucault nesse mesmo ano, juntamente com Jules Vuillemin (imagem 2). São o registro de expectativas, ambas frustradas, do retorno de Foucault a São Paulo, e testemunham o entusiasmo despertado pelo autor de As palavras e as coisas quando de sua primeira passagem pelo Departamento, em 1965. 
São Paulo, 4 de malo de 1966.

Exmo. Snr.

Prof. Michel Foucault

Tenho o prazer de informar V.Excla. que seu nome já fol nomalmente indicado à Direção desta Faculdade para dar um Curso de fitica, am substituição a outro pro fessor francês, 0 Prof. Michel Debrun. Não haverả nenhuma di ficuldade para a aprovação dessa indicação pelo Conselho Téc nico e Administrativo e pela Congregação da Faculdade .

Contamos, pois, com sua próxima vinda pa ra uma colaboração que será muito honrosa para nós.

V. Esxcia. poderá fazer desta carta o us so que se fizer necessário junto à Administração de sua Fa culdade.

Com mil cordiais cumprimentos.

\section{Livio Teixeira}

Diretor do Departamento de Filosofia da Faculdade de Filoso fla, ciências e Letras da Univer sidade de São Paulo.

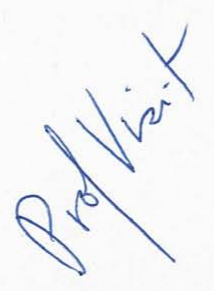

Imagem 1

Convite de Lívio Teixeira a Michel Foucault, comunicando sua escolha para ministrar o Curso de Ética. 


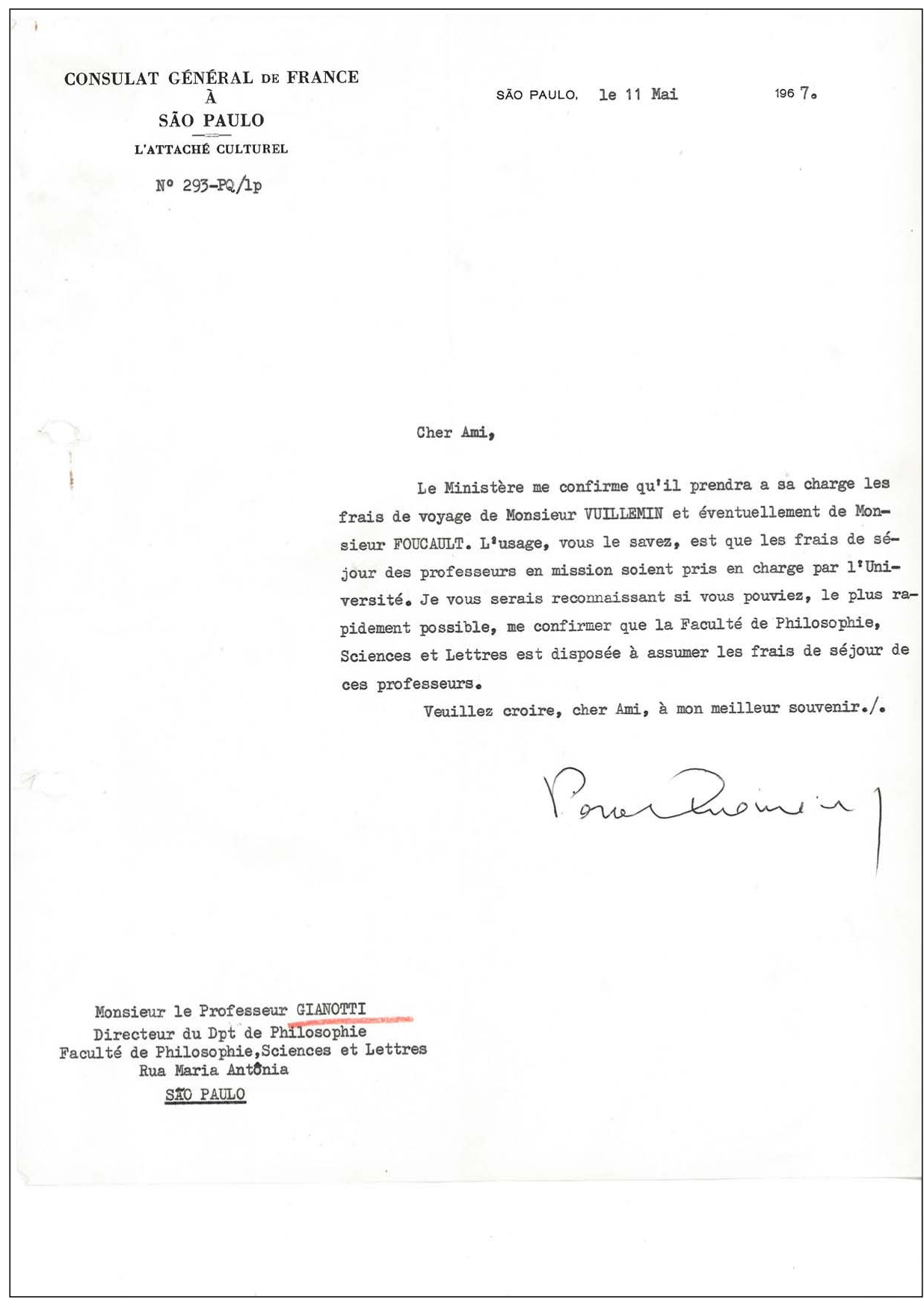

\section{Imagem 2}

Carta do cônsul francês a José

Arthur Giannotti, então Chefe do

Departamento de Filosofia da USP.

[1967] 


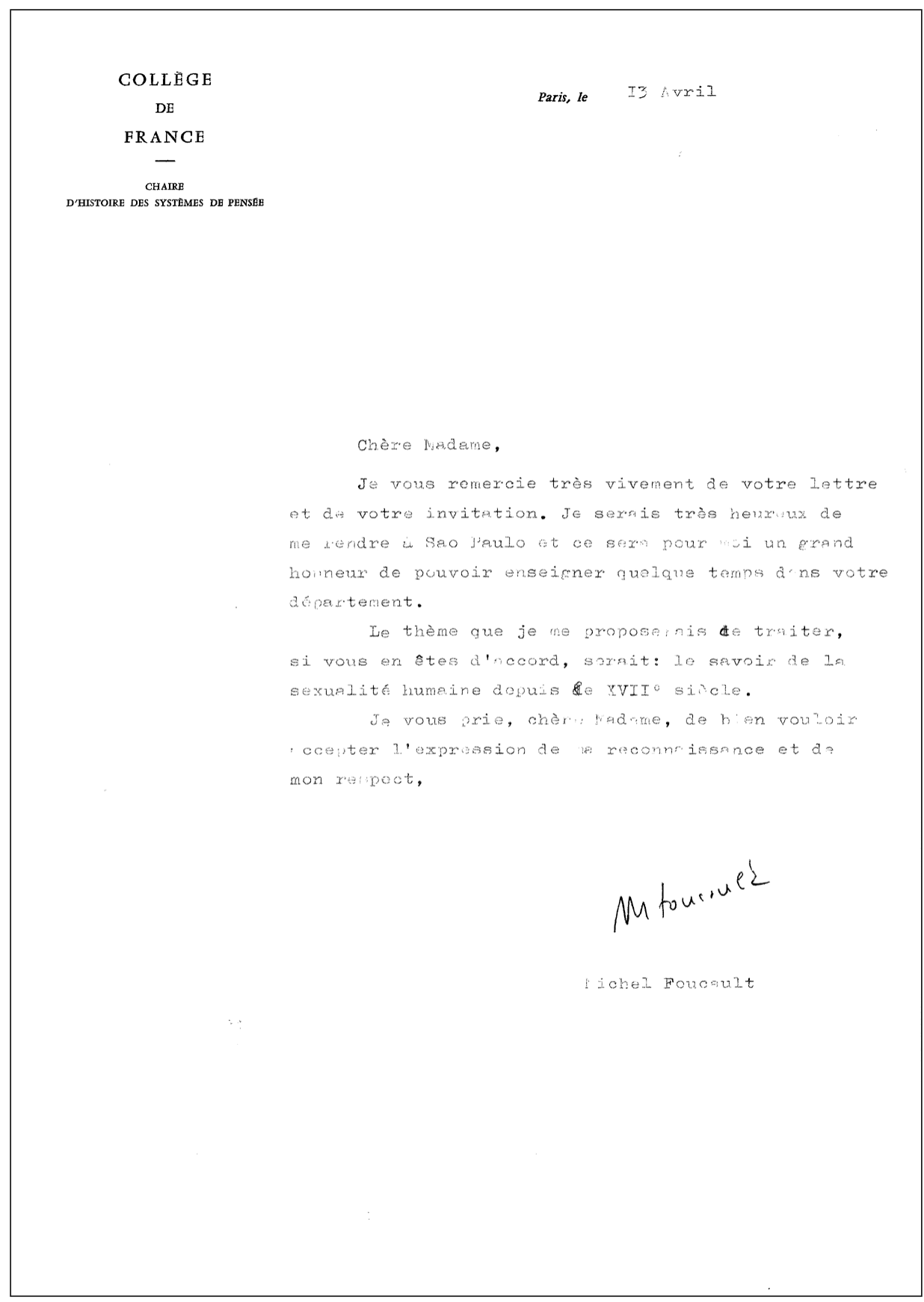

Imagem 3

Carta de Michel Foucault, na qual aceita o convite para sua vinda a São Paulo e comunica o tema de seu seminário: o saber sobre a sexualidade humana a partir do século XVII. [provavelmente 1974] 
UNIVERSIDADE DE SĀO PAULO FACULDADE DE FILOSOFIA, LETRAS E CIENCIAS HUMANAS

Hi. Ie Mrol.

ichel foucaut

285, Tue de Veugirara

Peris

Sæ̃o Paulo, Ie 24 Mar:s 1975

Cher Honsieur

Au nom du Département de Philosophie de l'Université de Paulo, j'ai I'honneur de vous communicuer oue nous venons de demander aux cervices culturels de 1'Ambassade de france au Brésil l'inaication de votre nom come professeur visitant pour le second sémestre de cette année. vous aurez en charge un prograrme de conférences ouvert aux Étudiarts de "pós-graduação" et de "graduação" dans leunel vous pourrez aborder des themes de votre choix.

Nous vous remmercions d'avoir fait si bon acceuil à notre invitation. Je vous prie, h. Le Profesceur, a agre er l'expression de mes sentiments distineus.

Maria Sylvia Carvalho Eranco

chef du Departement de Phjlosophie

\section{Imagem 4}

Carta de Maria Sylvia de Carvalho

Franco a Michel Foucault,

comunicando sua escolha como professor visitante.

[1975] 
Brmo. Snr.

George romet

D). Adido cultural do Consulado Geral da Prança

em são paulo.

Prezado Senhor,

Fm nome do Departamento de Filosoria da Universidade de São paulo, tenho a honra de indicar-ihe os nomes dos professo-f res Alain Grosrichard e Michel Foucaut, escolhidos pelo Departa-/ mento de Filosoria para ministrarem cursos de pós-graduacão junto/ ao bepartamento, no 20 semestre do corrente ano. Os referidos proresores jálam por nós consultados e manifestaran sua disposi-f जăo en aceitar o convite. Por essa razão, venho solicitar-ihe as devidas providencias para a indicacão desses nomes ao servico fran ces de Relacóes Culturais e para o paganento de suas despesas de/ viakem por esse serviço.

Antcoipadarente agradecida, perome aceitar a ex-/ ppessão de meus melhores sentimentos.

São Paulo, 2/ de março de 1975

Maria Sylvia de Carvalho Franco Moreira

Chefe do Departamento de Hilosofia

\section{Imagem 5}

Carta de Maria Sylvia Moreira ao adido cultural da França em São Paulo, solicitando providências para a vinda de Foucault ao Departamento de Filosofia da USP. 